\title{
Effect of different levels of row spacing and nitrogen on yield characters in roselle (Hibiscus sabdariffa var. sabdariffa)
}

\author{
E. ARIVAZHAGAN* AND A.K. RAJA
}

Department of Horticulture, Faculty of Agriculture, Annamalai University, ANNAMALAINAGAR (T.N.) INDIA

\begin{abstract}
Investigation was carried out to study the effect of different levels of nitrogen and spacing on the yield characters in roselle. A field trial was conducted in a Factorial Randomized Block Design with five levels of nitrogen $\left(50,100,150,200\right.$ and $\left.250 \mathrm{~kg}^{-1}\right)$ and three levels of row spacing $(60,90$ and $120 \mathrm{~cm})$. The results of the present study revealed that the spacing of $120 \times 75 \mathrm{~cm}$ and nitrogen application of 250 $\mathrm{kg} \mathrm{ha}^{-1}$ was found to be superior in improving the yield characters like number of flowers plant $\mathrm{t}^{-1}$, number of fruits plant ${ }^{-1}$, yield of fresh and dry calyces plant ${ }^{-1}$, yield of fresh and dry calyces yield plot $^{-1}$, yield of fresh and dry calyces ha ${ }^{-1}$, seed yield and dry matter production.
\end{abstract}

Key Words : Nitrogen, Spacing, Roselle, Yield

View Point Article : Arivazhagan, E. and Raja, A.K. (2015). Effect of different levels of row spacing and nitrogen on yield characters in roselle (Hibiscus sabdariffa var. sabdariffa). Internat. J. agric. Sci., 11 (1): 13-18.

Article History : Received : 07.04.2014; Revised : 19.10.2014; Accepted : 05.11.2014

\footnotetext{
* Author for correspondence
} 